Article

\title{
How Much Is Enough? Explaining the Continuous Transparency Conflict in TTIP
}

\author{
Niels Gheyle * and Ferdi De Ville \\ Centre for EU Studies, Department of Political Science, Ghent University, 9000 Ghent, Belgium; \\ E-Mails: niels.gheyle@ugent.be (N.G.), ferdi.deville@ugent.be (F.d.V.) \\ * Corresponding author
}

Submitted: 6 May 2017 | Accepted: 10 July 2017 | Published: 25 September 2017

\begin{abstract}
Transparency has been a central issue in the debate regarding the Transatlantic Trade and Investment Partnership (TTIP), especially on the side of the European Union (EU). The lack of transparency in the negotiating process has been one of the main criticisms of civil society organizations (CSOs). The European Commission (EC) has tried to gain support for the negotiations through various 'transparency initiatives'. Nonetheless, criticism by CSOs with regard to TTIP in general and the lack of transparency in specific remained prevalent. In this article, we explain this gap between various transparency initiatives implemented by the EC in TTIP and the expectations on the side of European CSOs. We perform a content analysis of position papers on transparency produced by CSOs, mainly in response to a European Ombudsman consultation, complemented by a number of official documents and targeted interviews. We find that the gap between the TTIP transparency initiatives and the expectations of CSOs can be explained by different views on what constitutes legitimate trade governance, and the role of transparency, participation, and accountability herein.
\end{abstract}

\section{Keywords}

accountability; European Union; legitimacy; participation; politicization; trade; transparency; TTIP

\section{Issue}

This article is part of the issue "EU Institutional Politics of Secrecy and Transparency in Foreign Affairs", edited by Vigjilenca Abazi and Johan Adriaensen (Maastricht University, The Netherlands).

(C) 2017 by the authors; licensee Cogitatio (Lisbon, Portugal). This article is licensed under a Creative Commons Attribution 4.0 International License (CC BY).

\section{Introduction}

The negotiations between the European Union (EU) and the United States (US) on the Transatlantic Trade and Investment Partnership (TTIP) have led to an unprecedented public debate. In particular, the lack of transparency was one of the main criticisms of civil society organizations (CSOs) ${ }^{1}$ with respect to these negotiations, particularly within the EU. Even though 'transparency' can have various meanings in different contexts (see Heald, 2006), it is here generally understood as public access to information about an organization's activities and policies (Tallberg, 2014). In response to this apparent lack of transparency, the European Commission (EC) introduced several measures to address these concerns. Nonetheless, CSOs remained unsatisfied and continued to criticize the opaqueness of the negotiations. This article aims to explain why transparency demands in the TTIP prevail after several transparency initiatives have been implemented.

Shortly after the launch of the TTIP negotiations in 2013, more than 80 organizations from the EU and the US wrote a letter to the then Presidents Barack Obama, José Manuel Barroso and Herman Van Rompuy expressing their 'opposition to the use of behind-closed-door trade negotiations to change and lower public interest measures for the sake of commercial interest' (Public Citizen, 2013). Together with the substantial issues of regula-

\footnotetext{
${ }^{1}$ With CSOs, we refer to 'non-market and nonstate organizations in which people organize themselves to pursue shared interests in the public domain' (United Nations Development Programme, 2013).
} 
tory cooperation and investment protection, the alleged lack of transparency of the negotiations was central in the majority of CSOs' campaigns. In response to these criticisms, increasing transparency has been the main response of the EC to (re)gain support for the negotiations. In the mission letter to his future Commissioner for Trade Cecilia Malmström, the current President of the EC JeanClaude Juncker wrote 'I will ask you to enhance transparency towards citizens and the European Parliament during all steps of the negotiations [of TTIP]' (Juncker, 2014 , p. 4). Underlining the importance of transparency, in its first weeks in office, the EC launched transparency initiatives committing to publishing information on meetings of its Commissioners and senior officials and providing greater access to documents relating to TTIP (Coremans, 2017; European Commission, 2014). Making trade policy more transparent was also one of the three pillars of the current Commission's trade policy strategy 'Trade for all' (European Commission, 2015a).

Nevertheless, criticism with regard to the transparency of the TTIP negotiations has not withered away. According to trade union confederations of the EU and the US 'the transparency we have called for has not been achieved' (European Trade Union Confederation [ETUC], 2016). Corporate Europe Observatory [CEO] (2015) argued that 'despite the public relations [TTIP is] still under a cloak of secrecy'. Greenpeace (2016) released leaked documents 'to bring some much-needed transparency to the debate on TTIP', and even The Economist (2016) concluded that 'transparency concerns were ignored'.

In this article, we explain why the transparency initiatives of the EC in TTIP have not succeeded in muting criticism of the negotiations, particularly those from CSOs. To do so, we perform a detailed analysis of the positions regarding transparency as expressed by CSOs, business, and the EC. We go on to compare the positions and try to explain the similarities and differences between them. We complement this analysis with two targeted interviews. The remainder of this article is structured as follows: in section two, we briefly explain how transparency questions came to penetrate the international trade system. Section three empirically analyzes business' and CSOs' transparency demands in TTIP, and the response of the Commission. Section four explains the continuing transparency conflict by tapping into the literature on legitimate global governance, different models of accountability and the role of transparency and participation in these. We conclude by discussing the implications of our findings for the literature and the practice of (transparency in) EU trade negotiations.

\section{Why Transparency Became an Issue in the Trade System}

As the nature of the post-war international trade system changed over time its legitimacy has increasingly been questioned.
During the first decades of the post-war period, the General Agreement on Tariffs and Trade (GATT), similarly to other Bretton Woods international organizations (IOs), were seen as facilitating coordination between states, while still allowing for national policy space to preserve domestic stability (Keohane \& Nye, 2001; Zürn, 2004). The fundamental rationale of this set-up lies in what John Ruggie (1982) famously dubbed 'embedded liberalism': oriented towards liberal multilateralism, but with national governments still in the driving seat as shock absorbers (cf. Rodrik, 1998). The mode of governance associated with this paradigm has been labeled 'executive multilateralism': 'governmental representatives from different countries coordinate their policies internationally, but with little national parliamentary control and away from public scrutiny' (Zürn, 2004). IOs hence operated as 'clubs' of negotiators who worked in technically advanced bargaining sessions with each other behind closed doors (Hocking, 2004; Keohane \& Nye, 2001).

In the trade regime specifically, the opaqueness of the working methods of the GATT and the EU were pervasive (Florini, 2003; Woolcock, 2010). However, for several decades this was seen as both effective, in reaching the goal of progressively liberalizing trade, and unproblematic, as the system had left sufficient space for governments to pursue domestic policies. When by the 1970s world tariffs became only a fraction of what they had been in the first years of the post-war period, other elements that hampered trade came into view, socalled 'non-tariff barriers' such as cross-national differences in regulation (Winslett, 2016). Especially since the Uruguay Round (1986-1994) and the transformation of the GATT into the World Trade Organization (WTO), we have witnessed an increase in the scope, depth and legal bite of the international trade system (Araujo, 2016; Horn, Mavroidis, \& Sapir, 2009). Trade negotiations had become more focused on 'behind-the-border barriers', while the meaning of what constitutes a trade 'barrier' expanded beyond clearly discriminatory policies (Lang, 2011, pp. 226-227). In this way, domestic regulations that reflect societal preferences in areas such as public services or social, environmental or health protection made their way onto the trade agenda (Woods \& Narlikar, 2001; Young \& Peterson, 2006; Zürn, 2004).

Awareness of this increased intrusion into sensitive domestic policy issues gradually led to the involvement of new actors in the international trade scene, such as parliaments, trade unions, but above all nongovernmental organizations (Aaronson, 2002; Young \& Peterson, 2006). At the turn of the millennium, coalitions of these actors were successful at (temporarily) blocking new initiatives such as the Multilateral Agreement on Investment in 1998 and the launch of a WTO trade negotiating round at Seattle in 1999 (Smith, 2001; Walter, 2001). NGOs in particular not only criticized the supposedly 'neoliberal' substance (e.g. Gill, 1998), but also the procedural characteristics of the trade system. They 
argued that since trade negotiations now have a more direct and significant impact on citizens' daily life, the trade system needs to be made more transparent and include non-traditional players in the process (Goldman, 1994; Hopewell, 2015). These demands were directed at the multilateral as well as the EU level. Trade policy in the $\mathrm{EU}$ in the past has been depicted-also by pundits-as informal and dominated by a 'relatively small expert policy community' (Woolcock, 2010). Hence, a combination of politicization of trade policy, together with the delegation of trade authority to the supranational level, has made for a 'potentially explosive mix' in the EU (Meunier, 2003).

Both the WTO as well as the EU have over the years responded to these criticisms by somewhat increasing transparency and involvement of NGOs. Since the early 2000s, the WTO has made more documents public, established an accessible website, accepted amicus curiae briefs in dispute settlement proceedings and organized annual public outreach events (cf. Smythe \& Smith, 2006; Woods \& Narlikar, 2001). At the level of the EU, a specifically trade-related Civil Society Dialogue has been established, but its significance for giving input to (and receiving feedback from) the trade policy-making process has been assessed as being modest at best (Dür \& De Bièvre, 2007; Hocking, 2004; Jarman, 2008). Despite (gradual) changes on both levels, the issue of transparency again became central to the TTIP debate.

\section{Demand and Supply of Transparency in TTIP}

Demands for increased transparency of trade negotiations have been very intense during the TTIP negotiations. It is not our aim to explain at length why this was the case. In brief, it can be argued that TTIP, through its enhanced focus on regulatory cooperation, would more than ever be about affecting domestic policies and that CSOs responded partly by reinforcing their demands for transparency (see De Ville \& Siles-Brügge, 2016). Our main goal is to analyze precisely what the demands of CSOs were in terms of transparency and how the European Commission has responded. This should allow us to explain in the next section why both continue to disagree regarding the question of transparency.

Empirically, we focus on the investigation that the European Ombudsman undertook in the fall of 2014 to evaluate transparency in the TTIP talks, as a direct response to the public outcry by CSOs. Contrary to the other contributions in this issue that focused more on the institutional side of the initiative (Abazi \& Adriaensen, 2017; Neuhold \& Năstase, 2017), we focus in particular on the public consultation. During the period from July to October 2014, organizations and individuals were invited to provide their input on three concrete questions related to transparency: (i) concrete measures the EC could take to make the TTIP negotiations more transparent; (ii) best practices identified in other organizations; (iii) how transparency might affect the outcome of negotiations. In total, 56 written contributions were provided by nongovernmental organizations (NGOs, 26), business organizations (16), trade unions (7), public service providers (4), and MEPs (3). Due to low numbers, we have excluded the latter two categories, which implies a total of 49 analyzed contributions. ${ }^{2}$ All contributions are freely accessible on the Ombudsman's website (OI/11/2014/RA). It is worth stressing that these contributions were provided before the new Commissioner took office (November 2014). By comparing these positions with the changes implemented by the new Commission we can highlight the similarities and differences between them.

We have manually analyzed the content of these contributions and systematically distilled the demands made by different types of groups concerning the transparency deficit. As we did not have any preconception of what would be demanded, we approached this analysis inductively and constructed categories along the way. In doing so, we ended up with three distinctions. First, even though the questions were formulated narrowly regarding 'transparency', several organizations made claims that relate more to the concept of 'participation': 'the presence of and activities by non-state actors within institutional mechanisms created by an organization' (Tallberg, 2014). Second, claims were either general or specific. Third, specific transparency claims could be broken down into demands for 'negotiating' documents (technical texts or inside information about the process) or 'explanatory' documents to help understand the technical texts or process. Table 1 below summarizes these distinctions and gives examples of what was coded where.

Specific demands were coded cautiously, meaning that whenever it was unclear how far the demand went (e.g. 'we want to know the position of the EU'), we coded this under the least demanding category (e.g. 'position paper', which is an explanatory document outlining the overall goal of the EU in a specific domain). Ambiguous statements were discussed jointly amongst the authors prior to coding. As will be shown later, we have constructed a table concerning (the number of) specific transparency demands. We have only included claims that were voiced at least three times, to exclude marginal demands. For participation, such a table is less instructive, given that demands were both more general, andwhen specific-more difficult to put under one heading. These are illustrated by characteristic examples.

Because there is considerable variation within both the business and CSO group, we have been careful not to over-generalize our findings. Nonetheless, the extent of coherence found within these groups was quite remarkable. Business groups, NGOs, and trade unions have often copy-pasted parts of (or sometimes entire) position

\footnotetext{
2 We have also excluded 257 individual submissions (which were grouped together by the Ombudsman) for two reasons. First, we are interested in the positions by (groups of) organizations, not by individuals. Second, many individual contributions were either copy-paste answers of NGO contributions or lacked any meaningful substance (such as: ‘I don't support TTIP').
} 
Table 1. Coding classification with examples.

\begin{tabular}{llll}
\hline & Transparency & Participation \\
\hline General & 'So far, attempts at more transparency & $\begin{array}{l}\text { 'Nade by the European Commission } \\
\text { regarding access to documents are either } \\
\text { weak or deceiving' }\end{array}$ & $\begin{array}{l}\text { 'the European Union should do more to } \\
\text { ensure a balanced participation in and } \\
\text { influence of interests on the negotiations' }\end{array}$ \\
\hline \multirow{3}{*}{ Specific } & 'Negotiating' & $\begin{array}{l}\text { 'The single most important transparency } \\
\text { reform around the TTIP negotiations } \\
\text { would be to make the negotiating text } \\
\text { public' }\end{array}$ & 'Public consultation before and after \\
& & 'An agenda prior to each round to allow \\
& for comments by interested stakeholders' & & \\
\cline { 2 - 4 } & 'Explanatory' & &
\end{tabular}

papers of others, adding to this sense of coherence. ${ }^{3}$ For NGOs, this is in line with the finding that transparency has been the one thing different groups could agree upon (see e.g. Gheyle, 2016). To be as clear as possible, we have put the abbreviation of the organization(s) next to quotes and claims. ${ }^{4}$

\subsection{Demands for Transparency}

\subsubsection{Business Associations}

Almost all business contributions laud and commend the Commission for the work on transparency that has already been done (BE, ESF, TABC, FI, IBEC, DI, BDI). ${ }^{5} \mathrm{Am}$ ChamEU argues that it is "hard to imagine what more could be done to enhance transparency without undermining the ability of the EU and US officials to discuss and negotiate' while the Swedish Industry Confederation warns that going further 'risk[s] compromising the negotiations'. The Commission is urged to demand more transparency from the negotiating partner (BE, CC, BDI, ESF) and to encourage Member States to improve on transparency (SWI, ESF) and to better explain the benefits of trade negotiations (BE).

BusinessEurope argues that the role of transparency is in part to 'dispel myths and misperceptions of the TTIP agreement allowing a fact-based public debate and to making the deal more accessible and relatable to the people' (BE). There is a focus on 'explaining' what the negotiations are about and what the possible benefits and risks are (ESF). With this in mind, they stress the legitimate need to keep things confidential in order for negotiations to succeed (BE, ESF, DI, BDI).

Business organizations do make several recommendations on how the situation could be improved. In line with the general idea of 'explaining' trade negotiations more to the public, the bulk of these concern 'explana- tory' documents and arrangements. All non-confidential documents should be put in an online register (FI, DI, ESF, SWI, VDA) and prior to each round an agenda should be published to allow for comments (BE, BDI, VDA). More attention should be given to the translation of technical texts into other languages (TABC) or to easy-tounderstand language explanations and summaries (FI, $\mathrm{BE}, \mathrm{DI}, \mathrm{SWI}, \mathrm{VDA})$. Recommendations to improve access to negotiating documents are scarce. The most common demand is that there should be up-to-date digital access to confidential documents for a restricted group of stakeholders through accredited password systems instead of the reading room practice (BE, ESF, DI, SWI).

In sum, the position of business on formal transparency could be summarized as 'make sure that what is already public is better disseminated and explained to the public'. This is in line with their general remark that the Commission has already done a lot, and going much further could harm the effectiveness or outcome of negotiations.

\subsubsection{Civil Society Organizations}

CSOs are much more critical in terms of what has been accomplished. Praise for the Commission is hardly present, and the improvements to date have been depicted as '[coming] from a very low base, and most of its actions have been neither meaningful nor sufficient' (EDRI), 'ad-hoc initiatives...and not part of a well-thought out overall strategy' (EPHA, TACD), 'weak or deceiving' (ACC), 'omitting whatever the Commission deems controversial' (CEO) or 'does not meet minimum satisfactory level of transparency and engagement with stakeholders' (BEUC). With respect to transparency claims, therefore, the recommendations are broad and very demanding. Table 2 summarizes which demands have been put forward by NGOs and trade unions.

\footnotetext{
${ }^{3}$ While submissions have been made both by EU-level (22/49) and national organizations (27/49), we did not find strong variation between both. National branches of trade unions and business organizations did seem to take a slightly stronger position. Neither did we see significant difference between CSOs that have institutionalized access to TTIP negotiators, for example as part of the TTIP Advisory Group, and other, outside organizations. We thank one of the anonymous referees for bringing this possibility to our attention.

${ }^{4}$ The full list of abbreviations can be found in the annex.

${ }^{5}$ An exception are agricultural business groups: while the umbrella organization Copa-Cogeca sides with the other business groups, the sectoral European Milk Board and Irish Creamery Milk Suppliers Association take positions similar to CSOs.
} 
Table 2. Specific transparency demands by CSO.

\begin{tabular}{|c|c|c|}
\hline Demand & \# & Asked by \\
\hline \multicolumn{3}{|l|}{ Negotiating documents } \\
\hline Textual proposals & 25 & $\begin{array}{l}\text { CEO, FOEE, TACD, TE, AI, FI, MPE, PC, BEUC, ACC, EDRI, } \\
\text { EPHA, FFII, BUND, CE, CWF, VB, WECF, FP, UM, ETUC, } \\
\text { ETUCE, TUC, GMB, UUI }\end{array}$ \\
\hline $\begin{array}{l}\text { List of meetings (and minutes) of EC officials with } \\
\text { third parties }\end{array}$ & 20 & $\begin{array}{l}\text { CEO, FOEE, TACD, TE, AI, FW, FI, IGO, BEUC, ACC, EDRI, } \\
\text { EMI, EPHA, BUND, CE, CWF, VB, WECF, FO, GMB }\end{array}$ \\
\hline Consolidated texts & 18 & $\begin{array}{l}\text { CEO, FOEE, TACD, TE, AI, FI, BEUC, ACC, EDRI, EPHA, } \\
\text { FFII, BUND, CE, VB, WECF, FP, UM, GMB }\end{array}$ \\
\hline Correspondence / submissions by third parties & 16 & $\begin{array}{l}\text { CEO, FOEE, TACD, TE, AI, FI, BEUC, ACC, EDRI, EMI, } \\
\text { EPHA, BUND, CE, CWF, VB, WECF }\end{array}$ \\
\hline Negotiating mandate & 16 & $\begin{array}{l}\text { CEO, TACD, AI, PC, BEUC, ACC, EDRI, EPHA, FFII, BUND, } \\
\text { CE, VB, FP, UM, GMB, UUI }\end{array}$ \\
\hline $\begin{array}{l}\text { Correspondence between EC and other institutional } \\
\text { bodies }\end{array}$ & 12 & $\begin{array}{l}\text { FOEE, TE, AI, FI, BEUC, ACC, EDRI, BUND, CE, CWF, VB, } \\
\text { WECF }\end{array}$ \\
\hline Drafts, non-papers & 8 & CEO, FOEE, TE, Al, FI, EDRI, WECF, GMB \\
\hline $\begin{array}{l}\text { Respond to 'Access to documents' requests in timely } \\
\text { fashion }\end{array}$ & 6 & CEO, AI, FW, EDRI, FFII, UUI \\
\hline Legal opinions & 4 & FFII, ETUC, TUC, UUI \\
\hline \multicolumn{3}{|l|}{ Explanatory documents } \\
\hline Meaningful briefings and state of play documents & 20 & $\begin{array}{l}\text { CEO, FOEE, TACD, TE, Al, FI, MPE, PC, BEUC, EMI, } \\
\text { EPHA, BUND, CE, CWF, VB, WECF, FP, ETUC, ETUCE, } \\
\text { TUC }\end{array}$ \\
\hline Position papers & 16 & $\begin{array}{l}\text { FOEE, TACD, TE, AI, FI, BEUC, ACC, BUND, CE, CWF, VB, } \\
\text { WECF, UM, ETUC, ETUCE, TUC }\end{array}$ \\
\hline Agendas of (content of) negotiating rounds & 15 & $\begin{array}{l}\text { CEO, FOEE, TACD, TE, AI, FI, MPE, PC, BEUC, ACC, } \\
\text { EPHA, BUND, CE, VB, WECF }\end{array}$ \\
\hline $\begin{array}{l}\text { Make documents easily accessible in an online } \\
\text { register }\end{array}$ & 11 & $\begin{array}{l}\text { CEO, TACD, FW, MPE, EDRI, EPHA, EMI, FFII, CE, ETUC, } \\
\text { TUC }\end{array}$ \\
\hline Translate documents & 5 & MPE, PC, ETUC, ETUCE, TUC \\
\hline $\begin{array}{l}\text { List of which documents are available and who has } \\
\text { access to them }\end{array}$ & 4 & BEUC, EMI, EPHA, VB \\
\hline
\end{tabular}

The most important difference is that NGOs put much more emphasis on negotiating than on merely explanatory documents. In particular, NGOs ask for broad access to official documents of the EU and the negotiating partners: the mandate, textual proposals by the EU and the consolidated version when the US tabled its position. In addition, they ask for a list of meetings of trade officials, and all correspondence by third parties sent to them and vice versa. The kind of explanatory documents asked for are detailed agendas and meaningful briefings relating to negotiating rounds. The added adjective 'meaningful' refers to-as EDRI put it-'substantive documents, not altered in any way when released and no 'mere summaries, agendas or minutes with no specific information or "propaganda texts".

Trade unions take up a middle-ground position, even though they tend towards the NGO position. They argue that as a general presumption, everything should be public, but they leave room for exceptions if there is a demonstrable need (such as strategic landing zones)
(ETUC, ETUCE, TUC). At least, position papers and (draft) offers should be circulated (ETUC, ETUCE, TUC, GMB, UUI). A new element they demand is the publication of legal documents containing the interpretation of draft negotiating texts or amendments (UUI, ETUC, TUC). When it comes to explanatory measures, they mainly stress the need for meaningful state of play and round reports (ETUC, ETUCE, TUC). Although the national trade unions which were analyzed (DM, VIZ, GMB, UUI) seem more critical than the European umbrella ETUC, the latter still demands several steps forward, and therefore we situate the aggregate trade union position as being close to the average NGO position. This is strengthened by the fact that three sectoral European trade union umbrellas (EPSU, EFJ, ETF) have co-signed a critical letter regarding transparency together with 250 NGOs (CEO, 2014).

In sum, while the focus of business groups with regard to transparency was on 'explaining' trade negotiations and texts to the public, CSOs differ in that they want access to the official documents of negotiations. 


\subsection{Demands for Participation}

As business organizations expressed their satisfaction with the current state of transparency in trade negotiations, they hardly called for other additional measures. Their claims to increase participation and stakeholder consultation are very scarce. Their sole demand in this category concerns the TTIP Advisory Group, which is a group of 16 civil society and business representatives that was established early in 2014. Recommendations in this respect are about expanding the group (BDI, VDA) and about the inner-workings, such as giving the $A G$ more time to comment on more comprehensive briefings on US positions (BE, DI, SI).

The scarcity of demands for increased participation by business becomes clear when compared to the way NGOs describe participation and its necessity as being a complement to transparency for enhancing legitimacy. First of all, several NGOs have mentioned how transparency is only a stepping-stone towards greater participation: 'Transparency must be a sine qua non prerequisite of trade negotiations as it brings wide-ranging benefits by enabling democratic participation and needed scrutiny in the process' (ACC); 'by disclosing and proactively publishing more information and documentation to citizens and civil society groups, the EU could more effectively open participatory mechanisms and foster healthy public debate' (AI); "openness enables citizens to participate more closely in the decision-making process' (ClientEarth).

Secondly, the difference between the demands of business and NGOs is demonstrated by how NGOs perceive transparency and participatory measures as being linked. ACCESS identifies six areas that need to be addressed together: access to documents, advisory groups, stakeholder dialogues, involvement of parliaments, reading rooms and identifying 'revolving doors'. The same goes for BEUC and TACD, who listed a whole range of claims both on transparency and participation and state that 'the proposals listed below need to be implemented and assessed in combination because they complement each other and only together they would lead as an endresult to a more credible trade deal'. TACD summarizes this point well: 'Why 'transparency'? Meaningful input by those directly affected by the negotiations will result in more balanced provisions of the agreement'.

Thirdly, existing participatory mechanisms have been a concern on their own. The 'Civil Society Dialogues' are still perceived more as briefings from the Commission, where a few questions are briefly raised at the end with only vague answers in response (EDRI, ACC, FP): 'these meetings do not enable the promised 'dialogue' to take place' (ACC). Public consultations offer 'a fig leaf of credibility to the policies adopted, they are in fact totally inadequate for gauging the needs or wishes of the citizens affected' (FW). Lastly, BEUC, as a member of the Advisory Group questioned 'to which extent the AG risks being a tool to white wash non-transparent processes' (BEUC).
Fourthly, when asked for best practices of transparency in other institutions, several examples came back repeatedly, which describe a very far-reaching view on the transparency-participation link. Both the WIPO negotiation process (see McIntosh, 2014), and the Aarhus convention are popular examples and are considered a hallmark of transparency and participation. Features of these include timely document releases, open meetings, and participatory rights in meetings and even drafting groups. By referring to these far-reaching best practices, NGOs again propose a different model of transparency and participation than what is currently in place.

Finally, there are also specific demands with respect to participation. To some extent, these are 'remedies' to the observed deficiencies with current channels outlined above. Most elaborate are the demands to improve the work of the Advisory Group. Texts being developed for future rounds (and merged legal texts) should be presented on a secure online platform, in a timely fashion to allow AG members to make sensible contributions on which the Commission should respond meaningfully (ACC, EMI, $B E U C, E P H A, E D R I)$. The selection process should be made more transparent (ACC, EDRI) and the group should be expanded to include more stakeholders (EDRI, FFII). The group should also be included in the negotiations more fully (EMI). Secondly, the stakeholder dialogues should resemble a true 'dialogue' between stakeholders and the Commission (ACC, FP, EDRI). The criteria to be involved in the CSD must be clearly spelt out (EDRI) and the meetings would be more meaningful if sector-specific roundtables were established to provide direct input, in which stakeholders have access to technical documents, and this participation has the potential to shape the strategy and positioning of the negotiations (ACC, FP).

Besides the meaningful upgrading of existing channels, public consultation at various stages of the negotiations is a popular, but heterogeneous, demand. For some, consultations should take place before and after every negotiating round (BUND), where a technical workshop is organized to engage in dialogue about certain parts of the text (MPE; PC). For others, consultations should be held on each aspect of trade that touches on EU and national rule-making (such as ISDS or regulatory cooperation) (FOEE, TE, WECF, Al, FP, CWF). A final suggestion is to hold consultations at key stages of the negotiations: prior to the launch, on the draft mandate, on initial position papers, and on the final draft consolidated legal text (TACD, BEUC, EPHA). Whatever the exact timing or constellation, all contributions ask for the results of these public consultations to be fully reflected in the positions that negotiators take.

Trade unions also plead for more and better participatory options (UUI, ETUC, GMB) and for a more genuine dialogue (ETUCE). They specifically demand that for sectoral aspects, DG TRADE would hold discussions in the existing sectoral social dialogue committees and create new ones when non-existent (ETUC, TUC). They support the Advisory Group in principle but think that having only 
two trade union representatives is insufficient and that it should be more involved in position formulation rather than simply reacting to positions that have already been made (GMB, TUC, ETUC). In general, again they seem to tend towards the NGO position, albeit with more emphasis on their own lack of participation (for those not included in the AG).

\subsection{The European Commission's Response}

Notwithstanding that the questions in her public consultation referred to rather more formal aspects of transparency (cf. supra), in her decision closing the inquiry, the Ombudsman concluded that the 'public consultation confirm [s] that citizens expect and demand the right to know and to participate when it comes to TTIP' (European Ombudsman, 2015, emphasis added). Her suggestions were included under three headings, two referring to transparency and one to participation, respectively: 'greater public access to negotiating documents', 'more proactive disclosure of documents' and 'more balanced and transparent public participation'. With regard to the latter, the Ombudsman's recommendations come down to ensuring that the Commission's contacts with CSOs make for a balanced representation and are 'transparent about participation', i.e. publishing details and substantial summaries of its contacts, including those at lower levels of the organization.

In its official response to this decision, 'the Commission appreciates the European Ombudsman's call for a more proactive approach to transparency and welcomes the suggestions made' (European Commission, 2015b, p. 1). It emphasized that on 7 January 2015, the Commission published, for the first time ever, eight EU textual proposals and a number of new position papers, accompanied by explanatory leaflets to make them more accessible to a wider audience. With regard to the Ombudsman's suggestion to ask the US to also publish 'common negotiating texts' and to justify explicitly if and when such requests are refused, the Commission stated that in the context of an international negotiation, the Commission's political commitment to transparency is limited to its own documents' (European Commission, 2015b), and that it has discussed transparency with the US repeatedly, but that the latter has explicitly asked the Commission not to publish US documents or consolidated texts. Consolidated documents have, however, been made available to all MEPs as well as Member State national parliamentarians. The Commission also responded negatively to the suggestion of the Ombudsman to publish proactively all relevant internal documents pertaining to the TTIP negotiations except in cases of justifiable exception as this would 'represent a disproportionate burden on the Commission services' (European Commission, 2015b, p. 3). With regard to public participation, the Commission reiterated its already implemented actions in terms of a 'TTIP Advisory Group, public consultations and stakeholder involvement' (European Commission, 2015b, pp. 4-8).

By analyzing the transparency changes since Commissioner Malmström took office, and following the Ombudsman's recommendations, we see a combination of reinforcing existing measures (such as the TTIP AG, stakeholders meetings during negotiating rounds and the publication of explanatory documents), with new steps (such as the publication of textual proposals). In this way, the EC has been able to address several of the specific demands raised by CSOs, albeit in a limited interpretation (see also CEO, 2015). Textual proposals have been published but in a piecemeal manner. ${ }^{6}$ Lists of meetings with policy officials have been made public, but are confined to the highest policy ranks, and without reports of what was discussed. Third party correspondence has been made public, but only with respect to Commissioner Malmström (and not, as several organizations demand, regarding the main negotiators as well). Besides these partial gaps, what is missing, according to a policy officer of BEUC, are the consolidated texts (which necessitates agreement with the US), and-above all-the application of these transparency changes towards other negotiations, especially concerning the mandate (interview 1 ). ${ }^{7}$

This maximalist across-the-board application of transparency is not shared by the EC, because they stress a balance between transparency and responsibility: there is a legitimate need to keep things confidential at several points in the process (interview 2 ). ${ }^{8}$ They have put most focus on increasing transparency towards the co-legislators, in order to enhance inter-interinstitutional relations. With respect to explanatory documents, the EC has acted in a very strong way, and there are numerous reader-friendly documents, agendas and round reports available. This is in line with the view that 'the best way to calm down people's concerns and fears, and to also stop and rebut myths, is to say what is really going on' (interview 2). In the same vein, the outreach of the Commissioner, her cabinet Members and senior DG Trade officials have been reinforced. As is widely recognized, Commissioner Malmström seems to have given the existing mechanisms greater priority and has adopted a more open 'style' towards CSOs.

With respect to participation, however, we do not see much convergence. The EC has considerably stepped up its interaction with the European Parliament and has reached out to other institutional partners, especially national parliaments. In relation to civil society, however, it merely reaffirmed its commitment to the AG, and to existing stakeholder mechanisms, such as the Civil Society Dialogue and debriefing 'breaks' during negotiation rounds. These installments were already in place and were part of the criticism of many of the CSO contribu-

\footnotetext{
${ }^{6}$ Several proposals, such as on procurement, ICT or pesticides are at the time of writing (June 2017) missing, however

7 Policy officer, BEUC.

${ }^{8}$ Policy assistant, European Commission.
} 
tions. Both the quality of these mechanisms and the absence of new ways in which civil society is involved in twoway deliberation of the negotiations are still missing, in the eyes of the critics.

\section{Explaining the Continuous Conflict}

Our analysis of the contributions of different groups on the issue of transparency in the TTIP negotiations shows that there are two sides: business organizations and the $\mathrm{EC}$ on one hand, and CSOs on the other. The difference in position between them is both a question of degree, and of kind. The continuous conflict is partly due to the fact that CSOs ask for a level of transparency that the Commission has not fully delivered, as the EC apparently does not share a maximalist interpretation of transparency. Furthermore, CSOs view transparency as inextricably linked to (allowing for their) participation, while for the EC participation applies predominantly to institutional partners. ${ }^{9}$ In sum, for the EC, transparency is primarily aimed at fostering citizens' trust by allowing them to understand what is being negotiated. For CSOs, transparency is just a stepping-stone that should allow citizens (through CSOs) to meaningfully participate in the negotiations, and only this can bring trust.

These different visions can be theoretically captured by the literature on accountability in IOs, which differentiates between a 'delegation model' and a 'participation model'. In an influential article, Grant \& Keohane (2005) tackle the pervasive issue of the (un)accountability of IOs such as the WTO. The main question of accountability, they argue, is 'who are the actors that have the right to hold someone to account?' (p. 31). One way of looking at this involves relying on formal strings of delegation-the so-called 'delegation model' of accountability. Organizations are accountable to those who have entrusted them power (e.g. states), and hence power is legitimate 'when it is authorized by the legitimizing consent of those who delegate it' (Grant \& Keohane, 2005). In this sense, there is no requirement for intense participation by non-state actors, given that they have not provided the mandate directly. Accountability here is primarily seen as vertical and concerned with compliance with rules and standards that have been laid down by a principal (Hood, 2010, p. 998). Certainly, there will need to be some transparency along these lines, but primarily towards these principals. Given that-along this reasoning - transparency can go 'too far', it is unlikely that claims for a maximalist interpretation will follow. Rather, transparency will be seen as an instrumental value (Heald, 2006) that in some situations can improve accountability.

A second model of accountability stresses that the people who are governed by an institution should be able to influence its direction (Grant \& Keohane, 2005; Nanz \& Steffek, 2004). If the rules of an international organization or agreement impact people's daily lives, then they should be able to have a say in the decision-making process. CSOs (who claim to represent the wider public) in this respect make normative claims for holding powerwielders to account to those groups that bear the burden of their policies (Keohane, 2005). Accountability in this sense is labeled the 'participation model' ${ }^{10}$ and directed towards the people or the community at large. The ideal is a fully transparent society, hence the presumption towards general openness and disclosure, rather than one involving strong rules about who should be allowed access to information (Hood, 2010, p. 1000). Maximal transparency should, in this view, allow meaningful participation of representative CSOs. Rather than having an instrumental value, transparency here is seen more as being a human right in itself (Birkinshaw, 2006).

Based on our analysis, the EC and business organizations clearly tend towards a delegation model of accountability, while CSOs' vision of transparency relates to a participation model of accountability. The EC negotiates international trade agreements based on a mandate given by the Council of the EU and has to report regularly to the European Parliament. There are thus two chains of accountability that link European citizens to the EU's trade negotiations and the Commission is of the opinion that it is primarily accountable to the two co-legislators that delegated it the authority to negotiate (interview 2). Hence, the EC feels that its responsibility to be transparent and to allow participation is first and foremost towards the Member States and the European Parliament. Some degree of transparency directly to the public should allow for meaningful understanding by citizens, to build trust and allow them to exercise control through national and European elections. In this vision, it makes sense that in its transparency initiatives, the EC has gone much further in giving access to documents to European and national parliamentarians (including access to consolidated texts) and in interacting with them, than to CSOs.

CSOs, in their participation model of accountability, see a crucial role for them to represent citizens in the opaque and closed world of international trade negotiations. They perceive the increased transparency towards and involvement of national and European parliamentarians as insufficient as the chains of delegation in EU trade negotiations are too long and the transparency initiatives still prevent European and national parliamentarians from fully engaging with citizens (for example through strict confidentiality requirements). Hence, they see themselves as crucial to fill the gap between international and European trade governance and the citizens. $^{11}$ To ensure accountable and hence legitimate

\footnotetext{
${ }^{9}$ Business organizations' lack of criticism on participation is obviously linked to their already well-established (informal) position in trade negotiations.

${ }^{10}$ This view is therefore closely connected to direct rather than representative forms of democracy.

${ }^{11}$ As suggested by one of the anonymous referees, CSOs could also participate in trade negotiations through the national level. While transparency and participation in trade negotiations within the Member States is outside of the scope of this article, the fact that CSOs insist so much on increasing transparency and participation at the EU level, and have not mentioned a single Member State in the Ombudsman's question about best practices, might show that they do not fully believe in this national route.
} 
trade negotiations, they demand access to all information about these negotiations and should be able to engage in meaningful dialogue with the institutions conducting the negotiations.

An alternative explanation for the continuous transparency complaints of CSOs is of course that their real frustration concerns the substance of TTIP with which they disagree as well as their lack of influence upon it. Transparency could be a handy 'rally point' with which it is difficult to disagree and which brings together diverse organizations with different substantial preferences in a joint coalition. Such 'tactical usage' of transparency is always possible, and impossible to falsify empirically because of observational equivalence with our interpretation above. But we believe this does not undermine our argument. CSOs have held a consistent position on transparency throughout the TTIP negotiations (and even since the contestation of globalization at the end of the 1990s), which - as we have shown - has not been fully accommodated. Moreover, the Ombudsman consultation central to our analysis came rather early on in the process, when it was not clear that CSOs would be unable to impact on the substance of the negotiations, so there should have been less reason to use the 'transparency argument' as a surrogate at that point.

\section{Discussion and Conclusion}

The empirical puzzle at the outset of this article concerned the question why CSOs still criticize the 'secrecy' of the TTIP negotiations after the Commission has initiated several transparency initiatives. To solve this question, we analyzed the contributions of CSOs and business organizations to a consultation by the European Ombudsman on transparency in TTIP and contrasted this with the position and actions of the EC. We found a clear difference between business organizations, who expressed their satisfaction with the transparency initiatives, and CSOs, who asked both for greater transparency that would go beyond 'explanatory' texts and above all complemented by more opportunities for equal as well as for more meaningful participation. Since then, the EC and its Commissioner for Trade have implemented the transparency mechanisms with more dedication, even though they disagree with a maximalist interpretation in which everything should be public as a rule. Moreover, few new initiatives to increase the participation of CSOs in the talks have been taken, even though CSOs clearly stress the importance hereof.

From the Commission's point of view, full transparency for and participation of CSOs is not seen as the most important aspect in a delegation model of accountability, in fact, it is even seen as potentially counterproductive. There is a legitimate need to keep things confidential while keeping the principals (co-legislators) as engaged as possible. CSOs, on the contrary, feel that their (and citizens') core interests are directly affected by TTIP, and therefore demand to not only have insight into all negotiating documents but also to be able to participate meaningfully. The two are seen as being two sides of the same coin (interview 1). Given these different views, it is not surprising that the reform efforts seem to have fallen on deaf ears with the broader civil society. While a shortcoming of our research has been the difficulty to rule out that CSOs use the 'transparency claim' strategically, the fact that their claims have been consistent and not fully accommodated reinforces the plausibility of our argument.

This article has both academic and societal relevance. Academically, we have linked debates about transparency to the insights of the literature on the legitimacy of IOs through the analysis of a specific politicized trade negotiation. By focusing on the gap between the demands of CSOs and the supply by the EC in TTIP, we showed that the enduring conflict on transparency can be explained by fundamentally different views on the requirements for legitimate trade negotiations. For the trade policy literature, this article underlines the significance of taking into account procedural preferences, besides substantial interests, to understand the dynamics of trade negotiations and positions taken by different societal groups. The societal relevance of this article is that it helps understand (part of) the conflict between the EC and CSOs regarding trade negotiations. As this conflict is rooted in different visions of legitimacy that have become more important as trade agreements became more intrusive into domestic politics, it is not expected to wither away easily (see also Zürn, 2014). In fact, the same transparency criticism has recently been voiced with respect to EU trade negotiations with Japan and Mexico, adding to the demand that initiatives be applied beyond TTIP.

There have recently been some analyses regarding the potential overlap between different approaches to transparency (which come with different transparency requirements) which relate to the dichotomy we identified in our case (see e.g. Abazi \& Tauschinsky, 2015 on trust and control approaches). It is, however, an open question if a quest for a middle-ground between such perspectives is feasible. In an era where attitudes towards elites and public authorities quickly turn to suspicion when the slightest hint of secrecy is politicized, less than full transparency might always be seen as problematic. The same goes for the apparent participation problem between the EC and CSOs. While the kind of extensive participation demanded by the latter might be overburdening for the former when taken to its extreme, relying solely on a small Advisory Group of representatives also bears the risk of (being perceived as) 'coopting' a selection of voices in order to legitimize the case for free trade, similar to what happened after the Seattle protests (Hocking, 2004; Hopewell, 2015). As shown, CSOs are not against this AG-system per se but consider it to be insufficient to incorporate a meaningful array of voices. It seems that to make the future EU trade governance more legitimate in the eyes of civil society, 
any elaboration of this future framework should also be made in a transparent and inclusive way.

\section{Acknowledgements}

We thank the participants of the EUSA Conference panel on 'EU Trade Policy: TTIP and Beyond' in Miami for their fruitful comments. The authors would also like to thank the two anonymous reviewers as well as the editors of this thematic issue for their insightful comments and suggestions.

\section{Conflict of Interests}

The authors declare no conflict of interests.

\section{References}

Aaronson, S. A. (2002). Taking trade to the streets: The lost history of public efforts to shape globalization. Ann Harbor, MI: University of Michigan Press.

Abazi, V., \& Adriaensen, J. (2017). Allies in transparency? Parliamentary, judicial and administrative interplays in the EU's international negotiations. Politics \& Governance, 5(3), 75-86.

Abazi, V., \& Tauschinsky, E. (2015). Reasons of control and trust: Grounding the public need for transparency in the European Union. Utrecht Law Review, 11(2), 78-90.

Araujo, B. A. M. (2016). The EU deep trade agenda: Law and policy. Oxford: Oxford University Press.

Birkinshaw, P. (2006). Transparency as a human right. In C. Hood \& D. Heald (Eds.), Transparency: The key to better governance? Proceedings of the British Academy 135 (Vol. 1, pp. 47-58). Oxford: Oxford University Press.

Coremans, E. (2017). From access to documents to consumption of information: The European Commission transparency policy for the TTIP negotiations. Politics \& Governance, 5(3), 29-39.

Corporate Europe Observatory. (2014, May 19). Civil society call for full transparency in EU-US trade negotiations. Brussels: Corporate Europe Observatory. Retrieved from https://corporateeurope.org/inter national-trade/2014/05/civil-society-call-full-transpar ency-eu-us-trade-negotiations

Corporate Europe Observatory. (2015, May 5). TTIP talks: Despite the PR, still under a cloak of secrecy. Brussels: Corporate Europe Observatory. Retrieved from https://corporateeurope.org/international-trade/20 15/05/ttip-talks-despite-pr-still-under-cloak-secrecy

De Ville, F., \& Siles-Brügge, G. (2016). TTIP: The truth about the Transatlantic Trade and Investment Partnership. Cambridge: Polity Press.

Dür, A., \& De Bièvre, D. (2007). Inclusion without influence? NGOs in European trade policy. Journal of Public Policy, 27(01), 79-101.

European Commission. (2014, November 25). Opening the windows: Commission commits to enhanced transparency. European Commission. Retrieved from http:// europa.eu/rapid/press-release_IP-14-2131_en.htm

European Commission. (2015a). Trade for all: Towards a more responsible trade and investment policy. Brussels: European Commission. Retrieved from http:// trade.ec.europa.eu/doclib/docs/2015/october/tra doc_153846.pdf

European Commission. (2015b). Comments of the Commission in reply to further suggestions from the European Ombudsman in her closing decision. European Commission. Retrieved from https:// www.ombudsman.europa.eu/en/cases/correspond ence.faces/en/59343/html.bookmark

European Ombudsman. (2015, January 6). Decision of the European Ombudsman closing her own-initiative inquiry OI/10/2014/RA concerning the European Commission. European Ombudsman. Retrieved from https://www.ombudsman.europa.eu/en/cases/deci sion.faces/en/58668/html.bookmark

European Trade Union Confederation. (2016, March 10). US and EU trade union leaders: TTIP negotiations 'on the wrong course'. European Trade Union Confederation. Retrieved from https://www.etuc.org/press/usand-eu-trade-union-leaders-ttip-negotiations-wrong -course\#.WO4h6kt2mSA

Florini, A. (2003). The coming democracy: New rules for running a new world. Washington, DC: Island Press.

Gheyle, N. (2016, July). Adding fuel to the flames. How TTIP reinvigorated the politicization of trade. Paper presented at the GIFTA workshop series 'Social and Labour Impacts of Free Trade Agreements', Brussels, Belgium.

Gill, S. (1998). New constitutionalism, democratization and global political economy. Global Change, Peace \& Security, 10(1), 23-38.

Goldman, P. (1994). The democratization of the development of United States trade policy. Cornell International Law Journal, 27(3), 631-695.

Grant, R. W., \& Keohane, R. O. (2005). Accountability and abuses of power in world politics. American Political Science Review, 99(1), 29-43.

Greenpeace. (2016). Leaked TTIP documents released. Greenpeace. Retrieved from http://www. greenpeace.org/eu-unit/en/News/2016/Leaked-TTIP -documents-released

Heald, D. (2006). Varieties of transparency. In C. Hood \& D. Heald (Eds.), Transparency: The key to better governance? Proceedings of the British Academy 135 (pp. 25-43). Oxford: Oxford University Press.

Hocking, B. (2004). Changing the terms of trade policy making: From the 'club' to the 'multistakeholder' model. World Trade Review, 3(1), 3-26.

Hood, C. (2010). Accountability and transparency: Siamese twins, matching parts, awkward couple? West European Politics, 33(5), 989-1009.

Hopewell, K. (2015). Multilateral trade governance as social field: Global civil society and the WTO. Review of 
International Political Economy, 22(6), 1128-1158.

Horn, H., Mavroidis, P. C., \& Sapir, A. (2009). Beyond the WTO. An anatomy of EU and US preferential trade agreements (Bruegel Blueprint Series VII). Brussels: Bruegel.

Jarman, H. (2008). The other side of the coin: Knowledge, NGOs and EU trade policy. Politics, 28(1), 26-32.

Juncker, J. (2014, November 1). Mission letter: Cecilia Malmström: Commissioner for Trade. Brussels: European Commission. Retrieved from https://ec.europa. eu/commission/sites/cwt/files/commissioner_mission _letters/malmstrom_en.pdf

Keohane, R. (2005, July 6). Abuse of power. Harvard International Review. Retrieved from http://hir. harvard.edu/defining-powerabuse-of-power

Keohane, R., \& Nye, J. S. (2001). Between centralization and fragmentation: The club model of multilateral cooperation and problems of democratic legitimacy (KSG Working Paper No. 01-004). Retrieved from https://papers.ssrn.com/sol3/papers.cfm?abstract_ id $=262175$

Lang, A. (2011). World trade law after neoliberalism: Reimagining the global economic order. Oxford: Oxford University Press.

Mclntosh, T. (2014, January 7). WIPO transparency wins praise, gaps remain. FreedomInfo.org. Retrieved from http://www.freedominfo.org/2014/01/wipotransparency-wins-praise-gaps-remain

Meunier, S. (2003). Trade policy and political legitimacy in the European Union. Comparative European Politics, 1(1), 67-90.

Nanz, P., \& Steffek, J. (2004). Global governance, participation and the public sphere. Government and Opposition, 39(2), 314-335.

Neuhold, C., \& Năstase, A. (2017). Transparency watchdog: Guarding the law and independent from politics? The relationship between the European Ombudsman and the European Parliament. Politics \& Governance, 5(3), 40-50.

Public Citizen. (2013, November 11). Letter to Obama alerting to NAFTA concerns. Washington, DC: Public Citizen. Retrieved from https://www.citizen.org/ documents/public-citizen-letter-to-obama-alertingto-tafta-concerns.pdf

Rodrik, D. (1998). Why do more open economies have bigger governments? Journal of Political Economy, 106(5), 997-1032.
Ruggie, J. G. (1982). International regimes, transactions, and change: Embedded liberalism in the postwar economic order. International organization, 36(2), 379-415.

Smith, J. (2001). Globalizing resistance: The battle of Seattle and the future of social movements. Mobilization: An International Quarterly, 6(1), 1-19.

Smythe, E., \& Smith, P. J. (2006). Legitimacy, transparency, and information technology: The world trade organization in an era of contentious trade politics. Global Governance: A Review of Multilateralism and International Organizations, 12(1), 31-53.

Tallberg, J. (2014). Transparency and openness. In J. K. Cogan, I. Hurd, \& I. Johnstone (Eds.), The Oxford handbook of international organizations (pp. 1170-1192). Oxford: Oxford University Press.

The Economist. (2016). Trading places: What the aversion to global trade says about Europe and America. The Economist. Retrieved from http://www.economist. com/news/europe/21697877-what-aversion-globaltrade-says-about-europe-and-america-trading-places

United Nations Development Programme. (2013, September). Working with civil society in foreign aid. Possibilities for South-South cooperation? (Report published by UNDP China). Beijing: United Nations Development Programme.

Walter, A. (2001). NGOs, business, and international investment: The multilateral agreement on investment, Seattle, and beyond. Global Governance, 7, 51-74.

Winslett, G. (2016). How regulations became the crux of trade politics. Journal of World Trade, 50(1), 47-70.

Woods, N., \& Narlikar, A. (2001). Governance and the limits of accountability: The WTO, the IMF, and the World Bank. International Social Science Journal, 53(170), 569-583.

Woolcock, S. (2010). European trade policy. In H. Wallace \& W. Wallace (Eds.), Policy-making in the European Union (Vol. 4, pp. 388-406). Oxford: Oxford University Press.

Young, A., \& Peterson, J. (2006). The EU and the new trade politics. Journal of European Public Policy, 13(6), 795-814.

Zürn, M. (2004). Global governance and legitimacy problems. Government and Opposition, 39(2), 260-287.

Zürn, M. (2014). The politicization of world politics and its effects: Eight propositions. European Political Science Review, 6(1), 47-71.

\section{About the Authors}

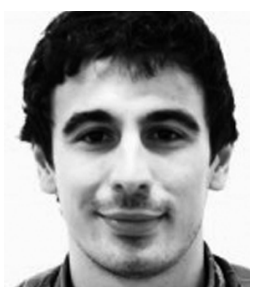

Niels Gheyle is a PhD Student at the Centre for EU Studies (Ghent University). His research concerns the origins, dynamics and consequences of the politicization of European trade policy, with a specific focus on the Transatlantic Trade and Investment Partnership (TTIP). 


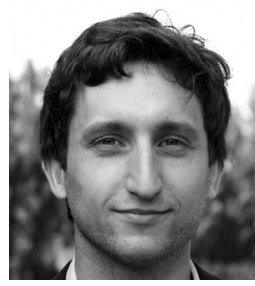

Ferdi De Ville is assistant professor in European Politics at the Centre for EU Studies, Ghent University. His research focuses on European political economy, and the politics of EU trade in particular. He is the co-author of TTIP: The Truth about the Transatlantic Trade and Investment Partnership (Polity Press). 
Annex

List of organizations with abbreviations

\begin{tabular}{|c|c|c|c|}
\hline Type & Full name & Abbrevation & Level \\
\hline NGO & Corporate Europe Observatory & CEO & Europe \\
\hline NGO & Friends of the Earth Europe & FOEE & Europe \\
\hline NGO & Transatlantic Consumer Dialogue & TACD & Transatlantic \\
\hline NGO & Transport \& Environment & $\mathrm{TE}$ & Europe \\
\hline NGO & Access Info & $\mathrm{Al}$ & Europe \\
\hline NGO & Food \& Water Europe & FW & Europe \\
\hline NGO & Forum Informationsfreiheit & $\mathrm{FI}$ & Austria \\
\hline NGO & Instytut Globalnej Odpowiedzialnosci Polska & IGO & Poland \\
\hline NGO & L'Assocation Environnement et Développement Alternatif & EDA & France \\
\hline NGO & Maison du Peuple d'Europe - Huis van het Volk van Europa & MPE & Europe \\
\hline NGO & Pacte Civique & PC & France \\
\hline NGO & European Consumer Organization & BEUC & Europe \\
\hline NGO & Access & ACC & International \\
\hline NGO & European Digital Rights Initiative & EDRi & Europe \\
\hline NGO & European Movement International & EMI & Europe \\
\hline NGO & European Public Health Alliance & EPHA & Europe \\
\hline NGO & Alpe Adria Green & AAG & Slovenia \\
\hline NGO & Foliovision & FO & Slovakia (EU focus) \\
\hline NGO & Foundation for a Free Information Infrastructure & FFII & Europe \\
\hline NGO & Friends of the Earth Germany & BUND & Germany \\
\hline NGO & Umweltinstitut München & UM & Germany \\
\hline NGO & Client Earth & CE & Europe \\
\hline NGO & Fundacja Panoptykon & FP & Poland \\
\hline NGO & Compassion in World Farming & CWF & UK \\
\hline NGO & Verbraucherzentrale Bundesverband e.V. & VB & Germany \\
\hline NGO & Women in Europe for a Common Future & WECF & Europe \\
\hline Business & Copa-Cogeca & CC & Europe \\
\hline Business & European Services Forum & ESF & Europe \\
\hline Business & Business Europe & $\mathrm{BE}$ & Europe \\
\hline Business & Transatlantic Business Council & TABC & Transatlantic \\
\hline Business & ELINKEINOELÄMÄN KESKUSLIITTO (Finnish Industries) & $\mathrm{FI}$ & Finland \\
\hline Business & Standing Committee of European Doctors & CPME & Europe \\
\hline Business & Bundesverband der Deutschen Industrie & BDI & Germany \\
\hline Business & Irish Creamery Milk Suppliers Association & ICMSA & Ireland \\
\hline Business & European Milk Board & EMB & Europe \\
\hline Business & American Chamber of Commerce to the EU & AmCham & Europe \\
\hline Business & Verband der Automobilindustrie & VDA & Germany \\
\hline Business & $\begin{array}{l}\text { Confederación Española de Organizaciones Empresariales } \\
\text { [Spanish Industry] }\end{array}$ & SI & Spain \\
\hline Business & Confederation of Danish Industry & DI & Denmark \\
\hline Business & Handwerkskammer für München und Oberbayern & HMO & Germany \\
\hline Business & Confederation of Swedish Enterprise & SWI & Sweden \\
\hline Business & Irish Business and Employers Confederation & IBEC & Ireland \\
\hline Trade Union & Dansk Magisterforening & DM & Denmark \\
\hline Trade Union & Sindikat Vzgoje, Izobraževanja, Znanosti in Kulture Slovenije & VIZ & Slovenia \\
\hline Trade Union & European Trade Union Committee for Education & ETUCE & Europe \\
\hline Trade Union & European Trade Union Confederation & ETUC & Europe \\
\hline Trade Union & Trades Union Congress & TUC & UK \\
\hline Trade Union & Unite the Union Ireland Region & UUI & Ireland \\
\hline Trade Union & GMB Trade Union & GMB & UK \\
\hline
\end{tabular}

